\title{
Coccidoxenoides perminutus parasitizing Planococcus citri on vine in Brazil
}

\author{
Coccidoxenoides perminutus parasitando Planococcus citri em videira no Brasil
}

\author{
Maria Herlândia de Araújo Fernandes ${ }^{I}$ José Eudes de Morais Oliveira ${ }^{I I}$ \\ Valmir Antônio Costa ${ }^{\text {III }}$ Karen Oliveira de Menezes $^{\text {IV }}$
}

\begin{abstract}
From those of the mealybug family, the citrus mealybug, Planococcus citri Risso, 1813 (Hemiptera: Pseudococcidae) is frequently held responsible for various diseases occurring in vineyards. This is a first time report in Brazil, on the occurrence of a parasitoid controlling $\boldsymbol{P}$. citri. In our search for the natural enemies of $\boldsymbol{P}$. citri, bunches of grapes with the vine were collected every week for one month, in those regions where table grapes were produced, like Petrolina, Pernambuco, Brazil. In these samples, among the natural pest infestations Coccidoxenoides perminutus Girault, 1915 (Hymenoptera: Encyrtidae) was the only natural enemy species reported. In this research, we attempted to study the potential of parasitism as well as the strategies that this natural agent uses in pest control.
\end{abstract}

- NOTE
Key words: citrus mealybug, biological control, parasitoid.

RESUMO

As cochonilhas-farinhentas, dentre elas Planococcus citri Risso, 1813 (Hemiptera: Pseudococcidae), são apontadas como responsáveis por ocasionar problemas fitossanitários na cultura da videira. Esta nota relata, pela primeira vez no Brasil, a ocorrência de um parasitoide no controle de P. citri. Para prospecção de inimigos naturais associados a $\boldsymbol{P}$. citri, foram realizadas coletas de cachos de uvas infestados por essa cochonilha-farinhenta, semanalmente, durante o periodo de um mês, em áreas de produção de uvas finas de mesa, com infestação natural da praga, no município de PetrolinaPE. Coccidoxenoides perminutus Girault, 1915 (Hymenoptera: Encyrtidae), foi a única espécie de inimigo natural obtida. A partir desse registro, pretende-se estudar o seu potencial de parasitismo, bem como as estratégias de uso desse agente de controle natural.

Palavras-chave: cochonilha-farinhenta, controle biológico, parasitoide.
In northeastern Brazil, particularly at the Lower Basin of San Francisco Valley, viticulture is one of the most explored cultures. However, pests, in any of the noted wine regions across the globe, are considered a major deterrent to the enlargement of the vineyard, due to their limiting activity on the vines (KUHN \& NICKEL, 1998).

The Pseudococcidae family, better known as the floury mealybug, include the 'suckers' that feed on the sap and are the major cause of plants damaging. In the vineyard, they destroy the stem, leaves, branches, berries and roots, resulting in either direct damage, which cause production losses or indirect, through virus vectors such as GLRaV 3, winding viruses (Grapevine leafroll associated virus 3), GVA (Grapevine trichovirus A) and GVB (Grapevine trichovirus B) (BERTIN et al., 2010). Apart from direct and indirect losses, the presence of organisms of quarantine importance like Pseudococcidae within the fruit clusters is one of the main reasons for the restrictions placed on the exported process (KISHINO et al., 2007).

In their search for emergency action control, producers incorporate immediate control measures frequently employing chemicals. Such indiscriminate chemical use has rendered the insect populations resistant to the growing numbers of

\footnotetext{
'Programa de Pós-graduação em Agronomia - Produção Vegetal, Universidade Federal do Vale do São Francisco (UNIVASF), Campus de Ciências Agrárias, BR 407, km 119, Lote 543, s/nº, 56300-990, Petrolina, PE, Brasil. E-mail: herlandia_fernandes@hotmail.com. Corresponding author.

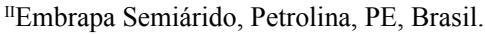

IIIInstituto Biológico - Centro Experimental Central do Instituto Biológico, Campinas, SP, Brasil.

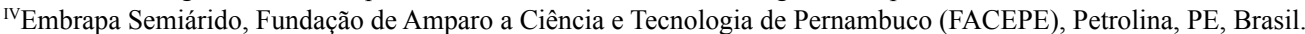
Received 03.12.15 Approved 12.10.15 Returned by the author 04.14.16 CR-2015-0357.R2
} 
insecticides produced (KNIGHT \& NORTON, 1989). Therefore, with the awareness of the damage produced by recurrent chemical usage, biological control utilizing parasitoids, may offer a promising and safe solution for managing the Pseudococcidae infestations in vines.

The insects of the Pseudococcidae family usually attack the grape vines in the Lower Basin region of the San Francisco Valley. Among the many species identified, Planococcus citri Risso, 1813 (Hemiptera: Pseudococcidae) is the most commonly encountered. Using their scales to identify the natural enemies associated with them, samples were collected from the regions in the Petrolina municipality where fine table grapes are cultivated. Every week $20 \boldsymbol{P}$. citri infested grape clusters were collected for one month. These were taken to the laboratory of Entomology at Embrapa Semi-Arid. Next, the insects were carefully transferred on to pumpkins and packed in wooden cases $(53.5 \times 43 \times 47.5 \mathrm{~cm})$. Each box had a glass sheet at the top, whereas the sides were covered with a fine mesh nylon screen and the front with a voile type of fabric. This was used as the breeding substrate, maintained under controlled conditions $\left(25 \pm 1^{\circ} \mathrm{C}\right.$, $60 \pm 10 \% \mathrm{RH}, 12 \mathrm{~h}$ photoperiod). Once the natural enemies emerged, the specimens were mounted and identified as species Coccidoxenoides perminutus Girault, 1915 (Hymenoptera: Encyrtidae) (Figure 1).
Identification up to the level of genus and species was done using the keys published by NOYES et al. (1997) and NOYES (2000), respectively. The specimens were then deposited in the entomophagous Insect Collection "Oscar Monte", at the Biological Institute, headquartered in Campinas, SP, in the Biological Control Laboratory.

The current study is the first time observation of $\boldsymbol{C}$. perminutus in $\boldsymbol{P}$. citri in the vine in Brazil. MENEZES JUNIOR (2000) had recorded the presence of some species of Coccidoxenoides in Pseudococcidae in Brazil, but had not determined the species. C. perminutus has been described under different synonyms in other parts of the world and the most commonly used is Pauridia peregrina Timberlake, 1919. However, the most recognized name in usage is $\boldsymbol{C}$. perminutus (NOYES \& PRINSLOO, 1998).

This endoparasitoid is uniparental, exhibiting thelytokous reproduction. It attacks all the instars of the mealybug (KRISHNAMOORTHY \& MANI, 1989). In their study CEBALLO \& WALTER (2004) explained that the $\boldsymbol{C}$. perminutus female lays eggs chiefly during the second instar nymphs of $\boldsymbol{P}$. citri. In the laboratory studies conducted at $28 \pm 2{ }^{\circ} \mathrm{C}$, it was observed that these parasitoids completed their life cycle between 23-27 days, and the surviving adult lived for 4-9 days (MANI \& KRISHNAMOORTHY,

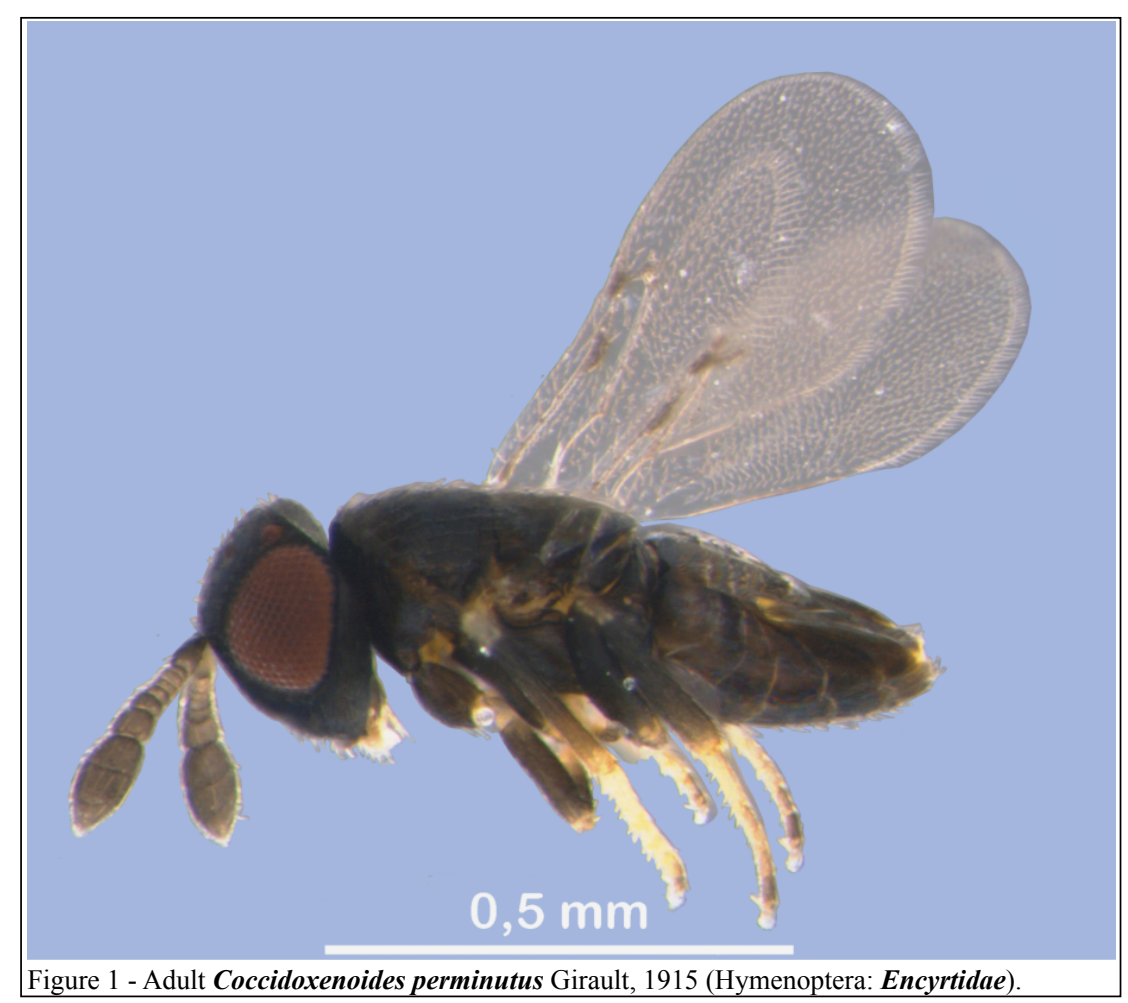

Ciência Rural, v.46, n.7, jul, 2016. 
1989). However, JOYCE et al. (2001) did not record the $\boldsymbol{C}$. perminutus female feeding on hemolymph host ("Host feeding").

C. perminutus is well recognized as a significant parasitoid of pseudococcídeos linked with the most diverse cultures, currently prevalent across the world in biological control programs. NOYES (2013) mentions its presence in many countries and in several hosts within the Pseudococcidae family; in South America, it was introduced in Chile (GONZÁLES \& ROJAS, 1966) and Peru (SALAZAR, 1971). This parasitoid was recorded to be in association with $\boldsymbol{P}$. citri in South Africa (WAKGARI \& GILIOMEE, 2003), Bermuda (BENNETT et al., 1959), Chile (GONZALEZ \& ROJAS, 1966), India (KRISHNAMOORTHY \& MANI, 1989) and Peru (SALAZAR, 1971). Of the many pseudococcídeos parasites, Maconellicoccus hirsutus Green, 1908 (HAYAT, 2006), the pink hibiscus mealybug, was most recently detected in Brazil (MARSARO JR, et al., 2013).

The parasitoid $C$. perminutus exerts good control over the pseudococcídeos in several parts of the world, although Queensland (Australia) reported minimal levels of this parasite in the citrus groves. One reason for this may be a result of poor tolerance to the low relative humidity of air and high temperatures, which combine to curtail female longevity. The availability of abundant food supplies in the form of nectar producing plants, could increase the activity of this parasitoid in the field (CEBALLO \& WALTER, 2005).

Due to the uniqueness of the Brazilian semiarid climatic conditions further studies are required and necessary to understand the bioecological and behavioral aspects of $\boldsymbol{C}$. perminutus under such conditions, in order to assess their effectiveness, feasibility and potential use in a biological control program.

\section{ACKNOWLEDGMENTS}

We sincerely thank the Fundação de Amparo a Ciência e Tecnologia de Pernambuco (FACEPE) for the financial assistance to Proc. No. APQ-0697-5.01 / 10 (APQ - FACEPE - 09/2010) and the Conselho Nacional de Desenvolvimento Científico e Tecnológico (CNPq) Proc. 482763 / 2012-4 (Universal Notice 14/2012).

\section{REFERENCES}

BENNETT, F.D.; HUGHES, I.W. Biological control of insect pests in Bermuda. Bulletin of Entomological Research, v.50, p.423-436, 1959. Available from: <http://journals.cambridge. org/action/displayAbstract? fromPage $=$ online \&aid $=2597868 \&$ full textType $=$ RA\&fileId $=$ S0007485300053025 $>$. Accessed: Apr. 15, 2014. doi: $10.1017 / \mathrm{S} 0007485300053025$.
BERTIN, S. et al. Survey of mealybugs (Hemiptera: Pseudococcidae) vectors of Ampelovirus and Vitivirus in vineyards of northwestern Italy. Photoparasitica, v.38, p.401409, 2010. Available from: <http://www.researchgate.net/ publication/225617509_Survey_of_mealybug_\%28Hemiptera Pseudococcidae\%29_vectors_of_Ampelovirus_and_Vitivirus_in_ vineyards_of_northwestern_Italy>. Accessed: May 27, 2015. doi: $10.1007 / \mathrm{S} 12600-010-0109-5$.

CEBALLO, F.A.; WALTER, G.H. Life history parameters and biocontrol potential of the mealybug parasitoid Coccidoxenoides peregrinus (Timberlake) (Hymenoptera: Encyrtidae): asexuality, fecundity and ovipositional patterns. Biological Control, v.29, p.235-244, 2004. Available from: <http://www.sciencedirect.com/ science/article/pii/S1049964403001518>. Accessed: Mar. 15, 2014. doi: 10.1016/S1049-9644(03)00151-8.

CEBALlO, F.A.; WALTER, G.H. Why is Coccidoxenoides perminutus, a mealybug parasitoid, ineffective as a biocontrol agent-Inaccurate measures of parasitism or low adult survival?. Biological Control, v.33, p.260-268, 2005. Available from: <http:// www.sciencedirect.com/science/article/pii/S1049964405000344>. Accessed: Jan. 20, 2014. doi: 10.1016/j.biocontrol.2005.02.009.

GONZALEZ, R.H.; ROJAS P.S. Estudio analítico del control biológico de plagas agrícolas en Chile. Agricultura Técnica, v.26, p.133-147, 1966.

HAYAT, M. Indian Encyrtidae (Hymenoptera: Chalcidoidea). India: Department of Zoology, Aligarh Muslim University, 2006. 496p.

JOYCE, A.L. et al. Oviposition behavior of Coccidoxenoides peregrinus, a parasitoid of Planococcus ficus. Entomologia Experimentalis et Applicata, v.98, p.49-57, 2001. Available from: <http://onlinelibrary.wiley.com/doi/10.1046/j.15707458.2001.00756.x/abstract?DeniedAccessCustomisedMessage $=$ \&userIsAuthenticated $=$ false $>$. Accessed: Apr. 24, 2014. doi: 10.1046/j.1570-7458.2001.00756.x.

KISHINO, A.Y. et al. Viticultura tropical o sistema de produção do Paraná. Londrina: IAPAR, 2007. 366p.

KNIGHT, A.L.; NORTON, G.W. Economies of agricultural pesticide resistance in arthropods. Annual Review of Entomology, v.34, p.293-313, 1989. Available from: $<$ http://www.annualreviews.org/doi/abs/10.1146/annurev. en.34.010189.001453?journalCode=ento $>$. Accessed: Jan. 25, 2014. doi: 10.1146/annurev.en.34.010189.001453.

KRISHNAMOORTHY, A.; MANI, M. Coccidoxenoides peregrina, a new parasitoid of Planococcus citri in India. Current Science, v.58, p.466-466, 1989. Available from: <http://www.currentscience. ac.in/Downloads/article_id_058_08_0466_0466_0.pdf > . Accessed: Apr. 17, 2014. doi: $10 . \overline{11} \overline{1} /$ ner. $121 \overline{1} 2$.

KUHN, G.B.; NICKEL, O. Viroses e sua importância na viticultura brasileira. Informe Agropecuário, v. 19, p.85-91, 1998.

MARSARO JÚNIOR, A.L. et al. First report of Maconellicoccus hirsutus (Green, 1908) (Hemiptera: Coccoidea: Pseudococcidae) and the associated parasitoid Anagyrus kamali Moursi, 1948 (Hymenoptera: Encyrtidae), in Brazil. Brazilian Journal of Biology, v.73, p.413-418, 2013. Available from: <http://www.scielo.br/scielo.php?pid=S151969842013000200413\&script $=$ sci_arttext $>$. Accessed: Feb. 24, 2014. doi: 10.1590/S1519-69842013000200024. 
MENEZES JUNIOR, A.O. Genera of Encyrtidae (Hymenoptera: Chalcidoidea) parasitoids of mealybugs (Hemiptera: Pseudococcidae) in Neotropical region. In: INTERNATIONAL CONGRESS OF ENTOMOLOGY, 21., 2000, Londrina, PR. Anais... Londrina: SEB, 2000. p.529.

NOYES, J.S. Encyrtidae of Costa Rica (Hymenoptera: Chalcidoidea), Part 1: The subfamily Tetracneminae, parasitoids of mealybugs (Homoptera: Pseudococcidae). Memoirs of the American Entomological Institute, v.62, p.168-170, 2000 .

NOYES, J.S. et al. Encyrtidae. In: GIBSON, G.A.P.et al. (Eds.) Annotated keys to the genera of Nearctic Chalcidoidea (Hymenoptera). Ottawa: NRC Research, 1997. p.170-320.

NOYES, J.S. Universal Chalcidoidea database. 2013. Online. Available from: <http://www.nhm.ac.uk/research-curation/ projects/chalcidoids/>. Accessed: Apr. 22, 2014.
NOYES, J.S.; PRINSLOO, G.L. A review of the Afrotropical and Malagasy taxa of Encyrtidae (Hymenoptera: Chalcidoidea) described by J. Risbec (1949-1959). Annales de la Société Entomologique de France, v.34, p.71-97, 1998.

SALAZAR T.J. Contribución al conocimiento de los Pseudococcidae del Perú. Revista Peruana de Entomología, v.15, p.277-303, 1971. Available from: <http://revperuentomol.com.pe/ publicaciones/vol15/PSEUDOCOCCIDAE-DEL-PERU277.pdf >. Accessed: Mar. 13, 2014.

WAKGARI, W.M.; GILIOMEE, J.H. Natural enemies of three mealybug species (Hemiptera: Pseudococcidae) found on citrus and effects of some insecticides on the mealybug parasitoid Coccidoxenoides peregrinus (Hymenoptera: Encyrtidae) in South Africa. Bulletin of Entomological Research, v.93, p.243-254, 2003. Available from: $<$ http://journals.cambridge.org/action/displayAbstract?fromPage $=$ onl ine\&aid=864600\&fulltextType=RA\&fileId=S0007485303000294>. Accessed: Apr. 2014. doi: 10.1079/BER2003235. 